\title{
Crude protein reduction with amino acid supplementation in tambaqui fingerling diets
}

\section{Redução de proteína bruta com suplementação de aminoácidos em rações para alevinos de tambaqui}

\author{
Charlyan de Sousa Lima ${ }^{1 *}$; Marcos Antonio Delmondes Bomfim²; \\ Jefferson Costa de Siqueira ${ }^{2}$; Eduardo Arruda Teixeira Lanna ${ }^{3}$; \\ Felipe Barbosa Ribeiro²; Danielli dos Santos Firmo ${ }^{4}$
}

\begin{abstract}
The aim of this study was to evaluate the effect that reduced crude protein (CP) diets with amino acid supplementation, based on the ideal protein concept, have on the performance of tambaqui fingerlings. In total, 750 fingerlings with an initial weight of $0.44 \pm 0.14 \mathrm{~g}$, were used in a completely randomized design, with six treatments, five replications, and 25 fish per experimental unit. Treatments consisted of six isocaloric, isocalcic, isophosphoric, and isolysinic diets containing 32.0, 30.5, 29.0, 27.5, 26.0, and $24.5 \%$ CP. Performance parameters, carcass yield, body composition (body humidity, protein, and fat content), and nitrogen retention efficiency (NRE) of the fish were evaluated. When the CP content was reduced to $27.5 \%$, there was an improvement in weight gain, specific growth rate, feed conversion, and protein efficiency rate. Feed intake was higher in fish fed diets containing $26 \% \mathrm{CP}$, followed by those fed diets containing 29 and $27.5 \% \mathrm{CP}$; diets containing other levels of $\mathrm{CP}$ did not differ among themselves. CP intake was reduced by the use of diets containing $24 \% \mathrm{CP}$, and the carcass yield was not influenced by the treatments. Reduced $\mathrm{CP}$ had no influence on body composition. NRE was higher in response to diets containing 26.0 and $24.5 \% \mathrm{CP}$. Reducing dietary CP content, from 32.0 to $24.5 \%$, based on the ideal protein concept, is possible for tambaqui fingerlings, and a decrease of up to $24.5 \%$ enhances the fish performance.
\end{abstract}

Key words: Amino acids, Colossoma macropomum, performance, protein nutrition

\section{Resumo}

Avaliou-se os efeitos da redução da proteína bruta (PB) com suplementação de aminoácidos, com base no conceito de proteína ideal, em rações no desempenho de alevinos de tambaqui. Utilizou-se 750 alevinos com peso inicial de $0,44 \pm 0,14 \mathrm{~g}$, em delineamento inteiramente casualizado, com 6 tratamentos, 5 repetições e 25 peixes por unidade experimental. Os tratamentos consistiram em 6 rações isoenergéticas, isocálcicas, isofosfóricas e isolisínicas com 32,$0 ; 30,5 ; 29,0 ; 27,5 ; 26,0 ; 24,5 \%$ de PB. Avaliaram-se as variáveis de desempenho, composição corporal (umidade, proteína e gordura corporais) e eficiência de

\footnotetext{
${ }^{1}$ M.e em Ciência Animal, Universidade Federal de Maranhão, UFMA, Campus de Chapadinha, Chapadinha, MA, Brasil. E-mail: charlyans1@yahoo.com.br

2 Profs. Adjuntos, UFMA, Campus de Chapadinha, Chapadinha, MA, Brasil. E-mail: madbomfim@yahoo.com.br; jcsiqueira@ ufma.br; felipebribeiro@yahoo.com

3 Prof. Adjunto III, Dept ${ }^{\circ}$ de Zootecnia, Universidade Federal de Viçosa, UFV, Viçosa, MG, Brasil. E-mail: eduardoalanna@yahoo. com.br

${ }^{4}$ Discente do Curso de Mestrado em Ciência de Animal, UFMA, Campus de Chapadinha, Chapadinha, MA, Brasil. E-mail: dsfeins@gmail.com

* Author for correspondence
} 
retenção de nitrogênio (ERN). Com a redução da PB a partir de 27,5\%, observou-se melhora no ganho de peso, na taxa de crescimento específico, na conversão alimentar e na taxa de eficiência proteica. $\mathrm{O}$ consumo de ração foi superior nos peixes alimentados com dietas contendo $26 \%$ de $\mathrm{PB}$, seguidos de 29,0 e $27,5 \%$ de $\mathrm{PB}$, os demais níveis não variaram entre si. O consumo de proteina bruta reduziu com a utilização da dieta com $24 \%$ de $\mathrm{PB}$ e o rendimento de carcaça não foi influenciado pelos tratamentos. A redução da $\mathrm{PB}$ não influenciou a composição corporal dos peixes. A ERN foi superior nos níveis de 26,0 a $24,5 \%$ de PB. É possível reduzir de 32,0 para $24,5 \%$ o teor de PB em rações, com base no conceito de proteina ideal, para alevinos de tambaqui, e a redução do teor de PB até o nível de $24,5 \%$ potencializa o desempenho dos peixes.

Palavras-chave: Aminoácidos, Colossoma macropomum, desempenho, nutrição proteica

\section{Introduction}

Proteins are the most expensive component in fishery diets and, when present at levels higher than the nutritional requirements of fish, lead to excessive nitrogen excretion. Nitrogen and phosphorus are the main agents responsible for the eutrophication of aquatic environments (BOMFIM et al., 2008; YAMAMOTO et al., 2005).

Fish need a quantitative balance of essential and non-essential amino acids. Diet formulations based on the crude protein requirements usually contain excessive levels of non-limiting amino acids (BOMFIM et al., 2008). In this sense, the reduction of dietary protein concentration with concomitant supplementation of limiting amino acids should improve the amino acid balance; this constitutes a strategy to reduce the nitrogen content excreted to the environment without causing any damage to the development and performance of fish (FRACALOSSI; CYRINO, 2013).

Currently, the ideal protein concept is recommended for fish diet formulation, which involves an exact balance of amino acids in order to meet each individual's requirements for maintenance and production. In this concept, the amino acid lysine is used as reference for the essential amino acids, mainly because it is industrially available, there is a significant amount of information regarding its requirements, it is easy to analyze, and a large proportion is used in protein synthesis (NRC, 2011; FRACALOSSI; CYRINO, 2013; TOLEDO et al., 2014).
Studies performed on Nile tilapia fingerlings (BOMFIM et al., 2008; FURUYA et al., 2005), show that it is possible to reduce the crude protein content up to $4 \%$ with supplementation of limiting amino acids in the industrial form, based on the ideal protein concept; however, higher reductions result in lower performance. Araripe et al. (2011) reported that performance was not compromised in tambatinga fish fingerlings tested with a diet containing a reduced crude protein content and supplemented with industrial amino acids. This variation in response may indicate that the viability of reduced protein diets, with limited amino acid supplementation, may differ between species.

One reason for reduced performance when the protein content is highly reduced is that the excessive use of industrial amino acids in diets might not have the same efficiency as amino acids obtained from the digestion of protein (FRACALOSSI; CYRINO, 2013). The lower efficiency of industrial amino acids might be due to their higher leaching, gastric emptying rate, and absorption when compared to the amino acids obtained from feed protein, leading to an imbalance of amino acids in the tissues specialized for protein synthesis (BOMFIM et al., 2008).

There is a lack of information regarding the viability of reduced protein content in diets that are supplemented with limiting amino acids in tambaqui fish based on the ideal protein concept.

Thus, this study aimed to evaluate the effects of a reduction in crude protein, with supplementation 
of limiting amino acids, based on the ideal protein concept, in the diets of tambaqui fingerlings (Colossoma macropomum).

\section{Materials and Methods}

This experiment was performed in the Fish Nutrition Research Sector of the Agricultural Sciences of the Federal University of Maranhão (UFMA), in the municipality of Chapadinha, Maranhão, for 45 days, from December 2012 to February 2013.
In total, 750 tambaqui fingerlings $(C$. macropomum) with an initial weight of $0.44 \pm$ $0.14 \mathrm{~g}$ were distributed in a completely randomized experimental design consisting of six treatments, five replicates, and 25 fish per experimental unit.

The treatments consisted of a control diet containing $32 \%$ crude protein $(\mathrm{CP})$, as recommended by Lima (2013), and five isocaloric, isocalcic, isophosphoric, and isolysinic experimental diets with a gradual reduction of $1.5 \%$ in crude protein content relative to the reference diet $(30.5 ; 29.0$; 27.5; 26.0; and 24.5\%) (Table 1).

Table 1. Percentage and chemical composition of experimental diets (natural material).

\begin{tabular}{|c|c|c|c|c|c|c|}
\hline \multirow{2}{*}{ Ingredients $(\%)$} & \multicolumn{6}{|c|}{ Crude Protein Content (\%) } \\
\hline & 32.00 & 30.50 & 29.00 & 27.50 & 26.00 & 24.50 \\
\hline Soybean meal (45\%) & 66.641 & 62.629 & 58.617 & 54.605 & 50.593 & 46.581 \\
\hline Corn & 23.664 & 27.652 & 31.641 & 35.629 & 39.618 & 43.606 \\
\hline Soybean oil & 5.029 & 4.794 & 4.558 & 4.323 & 4.088 & 3.852 \\
\hline L-Lysine-HCl (78.4\%) & 0.000 & 0.123 & 0.247 & 0.370 & 0.493 & 0.617 \\
\hline DL-Methionine (99\%) & 0.172 & 0.208 & 0.244 & 0.280 & 0.315 & 0.351 \\
\hline L-Threonine (98.5\%) & 0.164 & 0.220 & 0.276 & 0.332 & 0.388 & 0.443 \\
\hline L-Tryptophan (99\%) & 0.000 & 0.022 & 0.043 & 0.065 & 0.087 & 0.109 \\
\hline Calcitic limestone & 0.110 & 0.133 & 0.155 & 0.177 & 0.199 & 0.222 \\
\hline Dicalcium phosphate & 3.148 & 3.149 & 3.149 & 3.149 & 3.149 & 3.149 \\
\hline Vitamin and mineral supplement ${ }^{(1)}$ & 0.500 & 0.500 & 0.500 & 0.500 & 0.500 & 0.500 \\
\hline Vitamin $C^{(2)}$ & 0.050 & 0.050 & 0.050 & 0.050 & 0.050 & 0.050 \\
\hline Salt & 0.500 & 0.500 & 0.500 & 0.500 & 0.500 & 0.500 \\
\hline Antioxidant (BHT) & 0.020 & 0.020 & 0.020 & 0.020 & 0.020 & 0.020 \\
\hline \multicolumn{7}{|c|}{ Calculated composition ${ }^{(3)}$} \\
\hline Crude protein $(\%)$ & 32.00 & 30.50 & 29.00 & 27.50 & 26.00 & 24.50 \\
\hline Digestible protein $(\%)^{(4)}$ & 29.27 & 27.86 & 26.45 & 25.04 & 23.63 & 22.21 \\
\hline Digestible energy $\left(\mathrm{kcal} \mathrm{kg}^{-1}\right)^{(4)}$ & 3000.00 & 3000.00 & 3000.00 & 3000.00 & 3000.00 & 3000.00 \\
\hline Ether extract (\%) & 6.97 & 6.81 & 6.66 & 6.50 & 6.35 & 6.19 \\
\hline Crude fiber $(\%)$ & 3.94 & 3.80 & 3.65 & 3.51 & 3.37 & 3.22 \\
\hline Total Ca (\%) & 0.98 & 0.98 & 0.98 & 0.98 & 0.98 & 0.98 \\
\hline Available P/Phosphorous $(\%)^{(2)}$ & 0.70 & 0.70 & 0.70 & 0.70 & 0.70 & 0.70 \\
\hline Total Na (\%) & 0.22 & 0.22 & 0.22 & 0.22 & 0.22 & 0.22 \\
\hline Total lysine $(\%)$ & 1.914 & 1.908 & 1.902 & 1.896 & 1.889 & 1.883 \\
\hline Digest. lysine (\%) ${ }^{(4)}$ & 1.791 & 1.791 & 1.791 & 1.791 & 1.791 & 1.791 \\
\hline Total Met. + Cys (\%) & 1.102 & 1.099 & 1.096 & 1.093 & 1.091 & 1.088 \\
\hline Digest. Met. + Cys $(\%)^{(4)}$ & 1.020 & 1.020 & 1.020 & 1.020 & 1.020 & 1.020 \\
\hline Total threonine $(\%)$ & 1.424 & 1.420 & 1.416 & 1.413 & 1.409 & 1.405 \\
\hline
\end{tabular}




\begin{tabular}{lcccccc}
\multicolumn{1}{c}{ Continuation ... } \\
\hline Digest. threonine (\%) $)^{(4)}$ & 1.309 & 1.309 & 1.309 & 1.309 & 1.309 & 1.309 \\
Total tryptophan (\%) & 0.434 & 0.433 & 0.431 & 0.430 & 0.428 & 0.427 \\
Digest. tryptophan (\%) $)^{(4)}$ & 0.402 & 0.402 & 0.402 & 0.402 & 0.402 & 0.402 \\
DE/CP ratio (Kcal g ${ }^{-1}$ ) & 0.638 & 0.636 & 0.634 & 0.632 & 0.630 & 0.628 \\
Dig. Met + Cys. /lysine ratio & 56.9 & 56.9 & 56.9 & 56.9 & 56.9 & 56.9 \\
Dig. threonine/lysine ratio & 73.1 & 73.1 & 73.1 & 73.1 & 73.1 & 73.1 \\
Dig. tryptophan/lysine ratio & 22.4 & 22.4 & 22.4 & 22.4 & 22.4 & 22.4 \\
\hline
\end{tabular}

(1) Commercial vitamin and mineral supplement $\left(5 \mathrm{~kg} \mathrm{t}^{-1}\right)$, with the following nutritional levels per kilogram of product: Vit. A, 1.200.000 IU; Vit. D, 200.000 IU: Vit. E, 1.200 mg; Vit. K, 2.400 mg; Vit. B, 4.800 mg; Vit.B, 4.800 mg; Vit.B , 4.800 mg; Vit. $\mathrm{B}_{12}, 4.800 \mathrm{mg}$; Vit. C, $48 \mathrm{~g}$; Folic acid, $1.200 \mathrm{mg}$; Calcium pantothenate, $12.000 \mathrm{mg}$; Vit. C, $48.000 \mathrm{mg}$; biotin, $48 \mathrm{mg}$; choline chloride, 108 g; niacin, 24.000 mg; Fe, 50.000 mg; Cu, 3.000 mg; Mn, 20.000 mg; Zn, 30.000 mg; I, 100 mg; Co, 10 mg; Se, $100 \mathrm{mg} .{ }^{(2)}$ Vit. C: calcium salt ascorbic acid 2-monophosphate, $42 \%$ of active ingredient. ${ }^{(3)}$ According to the values proposed by Rostagno et al. (2011). ${ }^{(4)}$ Based on the phosphorous availability coefficients for Nile tilapia proposed by Furuya et al. (2010); and the coefficients for corn, soybean meal, and soybean oil proposed by Vidal Júnior (2000).

In order to make the isolysinic diets digestible, industrial lysine (L-lysine- $\mathrm{HCl}$ 78.4\%) was added to the diet as the protein content was reduced. The remaining amino acids were supplemented as the ratio between them and the digestible lysine became lower than the estimated values for the ideal protein required for Nile Tilapia as suggested by Furuya et al. (2010).

The fingerlings were maintained in 30 polyethylene aquarium tanks, with a volumetric capacity of $500 \mathrm{~L}$ and a useful volume of $300 \mathrm{~L}$, equipped with individual water supply and outflow systems, arranged in a recirculation system. The photoperiod was maintained with $12 \mathrm{~h}$ of light.

The water used to supply the aquarium tanks came from the artesian well of the Center of Agricultural and Environmental Sciences of the Federal University of Maranhão. The water temperature was monitored daily, at 7:30 am and 5:30 pm, with a mercury thermometer, graduated from 0 to $50^{\circ} \mathrm{C}$. The $\mathrm{pH}$, dissolved oxygen level in the water, and toxic ammonia were monitored every 7 days, with a $\mathrm{pH}$ meter, oximeter, and a commercial kit for toxic ammonia testing, respectively.

The diet ingredients were ground into pellets, using a meat grinder, manually crushed, and sieved (sieves with 10-16 mesh), generating pellets of 1.5$2.0 \mathrm{~mm}$ and $3.0-4.0 \mathrm{~mm}$. The diets were fed to the fingerlings ad libitum daily, at five different feeding times (8:00 am; 10:30 am; 1:00 pm; 3:30 pm; and 6:00 pm) and, at every meal, the diets were fed in small amounts with successive transfers, allowing the maximum intake until apparent satiety, thus avoiding leftovers and overfeeding. The aquarium tanks were cleaned twice daily to remove feces by siphoning, after the water temperature was measured.

The following indexes of performance, feed efficiency, and body composition were evaluated: feed intake (FI), crude protein intake (CPI), protein efficiency rate (PER), weight gain (WG), feed conversion (FC), specific growth rate (SGR), carcass yield, body composition (humidity, protein, and fat content), and nitrogen retention efficiency (NRE).

The FI was calculated as the amount of diet consumed from the beginning until the end of the experiment. The CPI was obtained by multiplying the feed intake by the protein percentage and dividing by 100 . The PER was obtained by dividing the weight gain by the CPI.

The WG was obtained by the difference between the average weight at the beginning and at the end of the experiment. The FC was calculated by dividing the apparent feed intake by the weight gain. In order to determine the SGR, the following equation was employed, using logarithmic transformations: 


$$
\mathrm{SGR}=\frac{\mathrm{LN} \text { of the final weight }(\mathrm{g})-\mathrm{LN} \text { of the initial weight }(\mathrm{g}) \times 100}{\text { Duration of the experiment }(\text { days })}
$$

A sample of 50 fish, which were anesthetized, euthanized, and frozen at the beginning of the experiment, was used to analyze body composition. All fish that were used in each experimental unit were used for analysis at the end of the experiment.

Before freezing, six fish from each experimental unit, with weights corresponding to the average weight of the unit, were eviscerated in order to determine the carcass yield. After freezing, the fish (carcass and offal) were lyophilized, milled in a ball mill, and packed into containers for laboratory analyzes. Laboratory analyzes of the body composition were performed at the Laboratory of Animal Nutrition of the State University of Maranhão, according to the procedures described by Silva and Queiroz (2002).

The carcass yield (\%) was calculated by dividing the weight of the eviscerated fish by the weight of the fish with the offal, multiplied by 100 . The nitrogen retention efficiency, expressed as a percentage, was calculated as the difference between the final and the initial body nitrogen values, divided by the total nitrogen intake, multiplied by 100 .

The performance and body composition variables were assessed for normality (Cramer-Von Mises) and homoscedasticity (Brown-Forsythe). When these assumptions were met, the variables were submitted to variance analysis and then compared using the Duncan test, considering a significance level of $\leq$ $5 \%$. For the nitrogen retention efficiency variable, the normality and homoscedasticity requirements were met after logarithmic transformation Log (x). The statistical analyses were performed using SAS 9.0 (2002) software.

\section{Results and Discussion}

Parameters obtained during the experimental period were: $27.0 \pm 0.40^{\circ} \mathrm{C}$ and $28.9 \pm 0.55^{\circ} \mathrm{C}$ for the water temperature in the morning and afternoon, respectively; $6.0 \pm 0.30$ for the $\mathrm{pH}, 6.6 \pm 0.36 \mathrm{mg}$ $\mathrm{L}^{-1}$ for the dissolved oxygen content, and $0.41 \pm$ $0.12 \mathrm{mg} \mathrm{L}^{-1}$ for the total ammonia, which were all within the recommended values for production of this species, according to Gomes et al. (2010) and Mendonça et al. (2012).

Only the fish fed with diets containing $26.0 \% \mathrm{CP}$ had an intake feed higher $(\mathrm{P}<0.05)$ than fish fed a control diet. The fish that were fed diets containing 27.5 and $29.0 \%$ CP showed intermediate intake values (Table 2).

Table 2. Performance, feed efficiency, and carcass yield in relation to the reduction of protein content of diets with amino acid supplementation in tambaqui fingerlings.

\begin{tabular}{lcccccccc}
\hline \multirow{2}{*}{\multicolumn{1}{c}{ Variables }} & \multicolumn{9}{c}{ Crude protein level (\%) } & \multirow{2}{*}{$\mathrm{CV}^{(1)}$} & \multirow{2}{*}{$\mathrm{P}>\mathrm{F}^{(2)}$} \\
\cline { 2 - 7 } Total feed intake $(\mathrm{g})$ & 32.0 & 30.5 & 29.0 & 27.5 & 26 & 24.5 & & \\
Total crude protein intake (mg) & $30.24^{\mathrm{b}}$ & $29.67^{\mathrm{b}}$ & $32.90^{\mathrm{ab}}$ & $34.25^{\mathrm{ab}}$ & $37.22^{\mathrm{a}}$ & $28.80^{\mathrm{b}}$ & 13.03 & 0.0955 \\
Protein efficiency rate & $9.68^{\mathrm{a}}$ & $9.05^{\mathrm{a}}$ & $9.54^{\mathrm{a}}$ & $9.42^{\mathrm{a}}$ & $9.68^{\mathrm{a}}$ & $7.06^{\mathrm{b}}$ & 12.38 & 0.0291 \\
Specific growth rate (\% day $\left.{ }^{-1}\right)$ & $1.36^{\mathrm{b}}$ & $1.86^{\mathrm{b}}$ & $1.70^{\mathrm{b}}$ & $3.49^{\mathrm{a}}$ & $4.04^{\mathrm{a}}$ & $4.30^{\mathrm{a}}$ & 25.83 & $<0.0001$ \\
Weight gain (g) & $7.93^{\mathrm{b}}$ & $8.44^{\mathrm{b}}$ & $8.20^{\mathrm{b}}$ & $10.04^{\mathrm{a}}$ & $10.36^{\mathrm{a}}$ & $9.83^{\mathrm{a}}$ & 9.66 & 0.0032 \\
Feed conversion $\left(\mathrm{g} \mathrm{g}^{-1}\right)$ & $13.37^{\mathrm{c}}$ & $17.15^{\mathrm{bc}}$ & $17.25^{\mathrm{bc}}$ & $33.12^{\mathrm{ab}}$ & $39.67^{\mathrm{a}}$ & $30.69^{\mathrm{ab}}$ & 39.75 & 0.0105 \\
Carcass yield (\%) & $2.60^{\mathrm{a}}$ & $2.02^{\mathrm{ab}}$ & $2.57^{\mathrm{a}}$ & $1.06^{\mathrm{b}}$ & $0.96^{\mathrm{b}}$ & $0.96^{\mathrm{b}}$ & 38.74 & 0.0024 \\
\hline
\end{tabular}

${ }^{(1)}$ Coefficient of variation (\%). ${ }^{(2)}$ Significance level of the "F" test for the analysis of variance. ${ }^{(3)}$ Means followed by the same letters in the same row did not differ significantly as determined by the Duncan Test $(\mathrm{P}>0.05)$. 
Regarding the results observed for the total feed intake, only the fish fed diets containing $24.5 \% \mathrm{CP}$ showed a lower total CPI $(\mathrm{P}<0.05)$ when compared to the fish fed the remaining experimental diets, which did not differ among themselves (Table 2). However, according to Araripe et al. (2011) and Bomfim et al. (2008), the CP intake in tambatinga and Nile tilapias, respectively, decreased with the reduction of protein content in diets supplemented with limiting amino acids.

The increase in total $\mathrm{CP}$ intake with the reduction in protein content in the diet (increase of the ratio between digestible energy (DE) and $\mathrm{CP}$ ) was also observed by Botaro et al. (2007). This effect may be associated with a better amino acid balance caused by the reduction of amino acids that would be in levels that exceeded the requirements of the animal, not contributing towards the formation of body protein, and being catabolized (BOMFIM et al., 2010) and, therefore, having an impact on the remaining parameters of performance and feed efficiency.

The protein efficiency rate was higher $(\mathrm{P}<$ 0.05 ) in the fish fed diets containing 27.5-24.5\% $\mathrm{CP}$ when compared to the remaining treatments, which did not differ among themselves. The higher protein efficiency achieved with the reduction of $\mathrm{CP}$ occurred because the control diet (32\% CP) consisted of amino acids at levels exceeding what is required by the fish, in comparison to the diets with reduced $\mathrm{CP}$ and amino acid supplementation (BOMFIM et al., 2008). These results show that fish, consistent with that observed in birds and swine, do not have protein requirements, but need an adequate balance of amino acids in order to meet maintenance and production needs (OLIVEIRA et al., 2014; RAMPE et al., 2014).

Tambaqui fingerlings used the industrial amino acids efficiently, even though these amino acids have low utilization efficiency, due to possible leaching and fast absorption (BALDISSEROTO, 2010). Given that the diets were provided as five daily meals and successive transfers, it is possible that this procedure matched the differences between the rates of industrial amino acid absorption and those obtained from protein sources (SOUZA et al., 2014). The higher the feeding frequency, the better the match between the concentration of industrial amino acids and those obtained from protein sources, therefore resulting in a higher protein efficiency, which is consistent with the results observed in this study (RIGHETTI et al., 2011; SOUZA et al., 2014; SANTOS et al., 2014).

Treatment involving a $\mathrm{CP}$ content between 27.5 and $24.5 \%$ led to higher weight gain (WG) and specific growth rate $(\mathrm{SGR})(\mathrm{P}<0.05)$ when compared to those containing $32.0 \% \mathrm{CP}$ (control diet). The remaining diets showed no differences from the control (Table 2).

The SGR values observed in this study were 4.16-4.53\% day $^{-1}$ higher than those observed by Souza et al. (2014), who analyzed the feeding frequency of juvenile tambaqui for 30 days; and were $0.89-0.98 \%$ day $^{-1}$ higher than the values obtained by Silva and Fujimoto (2015), who analyzed tambaqui in the growing phase for 98 days in aquiculture cages. The values obtained in this study were higher, which was possibly due to the use of fish during the initial growing phase, which is normally the developmental stage with the highest SGR values.

Regarding the weight gain, this improvement observed in the fish fed diets with reduced CP content may be associated with the higher feed intake (energy and nutrients) observed in the respective analyzed diets. This is probably due to the better amino acid balance in the diets with reduced CP content and limited amino acid supplementation (BOMFIM et al., 2008; TOLEDO et al., 2014). This response pattern is similar to that observed in grass carp (Ctenopharyngodon idella) by Gan et al. (2012). Similarly, in an experiment investigating rainbow-trout diets, Gaylord and Barrows (2009) showed that it is possible to reduce the CP content 
from 45 to $35 \%$, through supplementation with lysine, methionine, threonine, glycine, and taurine, without any loss of weight gain in the fish.

However, in other studies, no significant differences were observed in the weight gain of tambatinga (ARARIPE et al., 2011) and Nile tilapia (BOMFIM et al., 2008; RIGHETTI et al., 2011). Although no improvements were observed in the weight gain, such results suggest that the reduction of recommended CP content for these species is viable if there is adequate supplementation of amino acids.

As for feed conversion, the reduction of $\mathrm{CP}$ content in diets supplemented with amino acids and a CP content of 27.5-24.5\%, presented better values when compared to the remaining diets containing different CP contents and the reference diet (32\% of $\mathrm{CP}$ ), which did not differ among themselves (Table 2). The variation in feed conversion in this study is different from the results obtained by Righetti et al. (2011) in Nile tilapia, who observed a quadratic effect $(\mathrm{P}<0.05)$ for this variable in fish fed with a diet supplemented with industrial amino acids.

However, Araripe et al. (2011) and Botaro et al. (2007) did not observe statistically significant differences in feed conversion in tambatinga and Nile tilapia fingerlings, with diets that had a reduced content of crude protein and limiting amino acid supplementation.

Reduced feed conversion in the diets with a CP content between 27.5 and $24.5 \%$ when compared to the reference diet, may be due to the higher use of nutrients during production rather than maintenance processes (FRACALOSSI; CYRINO, 2013), as well as the more efficient use of industrial amino acids in diets with lower protein content (BOMFIM et al., 2008).

A reduction in the protein content of diets had no influence on the carcass yield (Table 2), body humidity $(\mathrm{BH})$, body fat $(\mathrm{BF})$, and body protein (BP) (Table 3).

Table 3. Body composition, deposition of body protein and fat, and nitrogen retention efficiency in tambaqui fingerlings fed with diets containing different protein contents.

\begin{tabular}{|c|c|c|c|c|c|c|c|c|c|}
\hline \multirow{2}{*}{ Variables } & \multicolumn{7}{|c|}{ Crude Protein content $(\%)$} & \multirow{2}{*}{$\mathrm{CV}^{(1)}$} & \multirow{2}{*}{$\mathrm{P}>\mathrm{F}^{(2)}$} \\
\hline & Initial & 32.0 & 30.5 & 29.0 & 27.5 & 26 & 24.5 & & \\
\hline Body humidity (\%) & 72.48 & 81.19 & 81.17 & 81.41 & 80.94 & 81.94 & 81.84 & 1.61 & 0.8026 \\
\hline Body fat (\%) & 1.21 & 1.31 & 2.01 & 1.78 & 1.27 & 1.88 & 1.27 & 32.86 & 0.1164 \\
\hline Body protein (\%) & 20.87 & 11.73 & 12.95 & 12.29 & 11.68 & 13.87 & 12.48 & 16.45 & 0.5580 \\
\hline $\begin{array}{l}\text { Nitrogen Retention } \\
\text { Efficiency }(\%)^{(3,4)}\end{array}$ & --- & $21.65^{\mathrm{b}}$ & $32.07^{\mathrm{ab}}$ & $29.56^{\mathrm{ab}}$ & $35.44^{\mathrm{ab}}$ & $47.88^{\mathrm{a}}$ & $47.72^{\mathrm{a}}$ & 18.16 & 0.1462 \\
\hline
\end{tabular}

${ }^{(1)}$ Coefficient of variation (\%). ${ }^{(2)}$ Significance level of the "F" test for the analysis of variance. ${ }^{(3)}$ The analyses were performed with $(\log (\mathrm{x}))$ transformed data. ${ }^{(4)}$ Means followed by the same letters in the same row did not differ significantly, as determined by the Duncan Test $(\mathrm{P}>0.05)$.

These results differ from those observed in trout by Yamamoto et al. (2005), who observed that in fish fed diets containing higher protein content, the content of body fat was lower. This was associated with the caloric expenditure needed to metabolize the excessive amino acids by the animals, resulting in a lower net energy and higher caloric increase (FRACALOSSI; CYRINO, 2013).

By reducing the protein content in the diets, we observed increased nitrogen retention efficiency in tambaqui fingerlings in the diets with lowest protein content, mainly in those containing 26.0 
and $24.5 \%$ of $\mathrm{CP}$, in comparison to the fish fed with diets containing $32.0 \%$ CP. Similar responses were observed in other studies on Nile tilapias (FURUYA et al., 2005; QUADROS et al., 2009) and rainbow-trout (YAMAMOTO et al., 2005), in which increased protein retention was observed as the amino acid balance was improved in the diets with the lowest protein content; therefore, reducing the nitrogen excretion to the environment.

Based on these results, the formulation of diets with a reduced protein fraction, supplemented with limiting amino acids based on the ideal protein concept, corroborates the observations performed in other species as an efficient way to reduce the polluting potential of this activity, without compromising fish development (ARARIPE et al., 2011; BOMFIM et al., 2008).

\section{Conclusions}

It is possible to reduce the protein content in diets to $32.0-24.5 \%$ for tambaqui fingerlings if the diets are supplemented with limiting amino acids, based on the ideal protein concept; and reducing the $\mathrm{CP}$ content up to $24.5 \%$, potentiates the development of the fish.

\section{Acknowledgements}

To the State Funding Agency of Maranhão (FAPEMA), for funding.

\section{References}

ARARIPE, M. N. B. A.; ARARIPE, H. G. A.; LOPES, J. B.; CASTRO, P. L.; BRAGA, T. E. A.; FERREIRA, A. H. C.; ABREU, M. L. T. Redução da proteína bruta com suplementação de aminoácidos em rações para alevinos de tambatinga. Revista Brasileira de Zootecnia, Viçosa, MG, v. 40, n. 9, p. 1845-1850, 2011.

BALDISSEROTO, B. Fisiologia de peixes aplicada à piscicultura. 2. ed. Santa Maria: UFSM, 2010. 352 p.
BOMFIM, M. A. D.; LANNA, E. A. T.; DONZELE, J. L.; ABREU, M. L. T.; RIBEIRO, F. B.; QUADROS, M. Redução de proteína bruta com suplementação de aminoácidos, com base no conceito de proteína ideal, em rações para alevinos de tilápia-do-nilo. Revista Brasileira de Zootecnia, Viçosa, MG, v. 37, n. 10, p. 1713-1720, 2008.

BOMFIM, M. A. D.; LANNA, E. A. T.; DONZELLE, J. L.; QUADROS, M.; RIBEIRO, F. B.; SOUSA, M. P. Níveis de lisina, com base no conceito de proteína ideal, em rações para alevinos de tilápia-do-nilo. Revista Brasileira de Zootecnia, Viçosa, MG, v. 39, n. 1, p. 1-8, 2010.

BOTARO, D.; FURUYA, W. M.; SILVA, L. C. R.; SANTOS, L. D.; SILVA, T. S. C.; SANTOS, V. G. Redução da proteína da dieta com base no conceito de proteína ideal para tilápias-do-nilo (Oreochromis niloticus) criadas em tanques-rede. Revista Brasileira de Zootecnia, Viçosa, MG, v. 36, n. 3, p. 517-525, 2007.

FRACALOSSI, D. M.; CYRINO, J. E. P. Nutriaqua: nutrição e alimentação de espécies de interesse para a aquicultura brasileira. Florianópolis: Sociedade Brasileira de Aquicultura e Biologia Aquática, 2013. 375 p.

FURUYA, W. M.; BOTARO, D.; MACEDO, R. M. G.; SANTOS, V. G.; SILVA, L. C. R.; SILVA T. C.; FURUYA, V. R. B.; SALES, P. J. P. Aplicação do conceito de proteína ideal para redução dos níveis de proteína em dietas para tilapia-do-Nilo (Oreochromis niloticus). Revista Brasileira de Zootecnia, Viçosa, MG, v. 34, n. 5, p. 1433-1441, 2005.

FURUYA, W. M.; PEZZATO, L. E.; BARROS, M. M.; BOSCOLO, W. R.; CYRINO, J. E. P.; FURUYA, V. R. B.; FEIDEN, A. Tabelas brasileiras para nutrição de tilápias. Toledo: GFM, 2010. 100 p.

GAN, L.; LIU, Y. J.; TIAN, L. X.; YANG, H. J.; YUE, Y. R.; CHEN, Y. J.; LIANG, J. J.; LIANG, G. Y. Effect of dietary protein reduction with lysine and methionine supplementation on growth performance, body composition and total ammonia nitrogen excretion of juvenile grass carp, Ctenopharyngodon idella. Aquaculture Nutrition, Malden, v. 18, n. 6, p. 589-598, 2012.

GAYLORD, T. G.; BARROWS, F. T. Multiple amino acid supplementations to reduce dietary protein in plant-based rainbow trout, Oncorhynchus mykiss, feeds. Aquaculture, v. 287, n. 1-2, p. 180-184, 2009.

GOMES, L. C.; SIMÕES, L. N.; ARAÚJO-LIMA, C. A. R. M. Tambaqui (Colossoma macropomum). In: BALDISSEROTTO, B.; GOMES, L. C. (Org.). Espécies nativas para piscicultura no Brasil. 2. ed. Santa Maria: Editora UFSM, 2010. p. 175-204. 
LIMA, C. S. Proteína bruta em rações para alevinos de tambaqui e sua redução com suplementação de aminoácidos. 2013. Dissertação (Mestrado em Ciência Animal) - Universidade Federal do Maranhão, Chapadinha.

MENDONÇA, P. P.; COSTA, P. C.; POLESE, M. F.; VIDAL JÚNIOR, M. V.; ANDRADE, D. R. Efeito da suplementação de fitase na alimentação de juvenis de tambaqui (Colossoma macropomum). Archivos de Zootecnia, Córbota, v. 61, n. 235, p. 437-448, 2012.

NATIONAL RESEARCH COUNCIL - NRC. Nutrient requirements of fish and shrimp. Washington: National Academy of Science, 2011. 376 p.

OLIVEIRA, F. L.; SIQUEIRA, J. C.; SANTOS, J. C. S.; PEREIRA, W. G. Equações de predição da energia digestível de ingredientes proteicos de origem vegetal utilizados em rações para tilápias. Cadernos Pesquisa, São Luís, v. 21, p. 1-9, 2014. Número Especial.

QUADROS, M.; LANNA, E. A. T.; DONZELES, J. L.; ABREU, M. L. T.; RIBEIRO, F. B.; TAKISHITA, S. S. Crudeprotein reduction and digestiblemethionine+cystine and threonine to digestible lysine ratios in diets for Nile tilapia fingerlings. Revista Brasileira de Zootecnia, Viçosa, MG, v. 38, n. 8, p. 1400-1406, 2009.

RAMPE, M. C. C.; PACHECO, M. L.; VARGAS JÚNIOR, J. G.; GIANNOTTI, J. D. G.; DEMUNER, L. F.; MARIN, J. F. V. Adição de lisina digestível em rações experimentais para juvenis de tilápia-do-nilo. Arquivo Brasileiro de Medicina Veterinária e Zootecnia, Belo Horizonte, MG, v. 66, n. 5, p. 1557-1566, 2014.

RIGHETTI, J. S.; FURUYA, W. M.; CONEJERO, C. I.; GRACIANO, T. S.; VIDAL, L. V. O.; MICHELLATO, M. Redução da proteína em dietas para tilápias-do-nilo por meio da suplementação de aminoácidos com base no conceito de proteína ideal. Revista Brasileira Zootecnia, Viçosa, MG, v. 40, n. 3, p. 469-476, 2011.

ROSTAGNO, R. S.; ALBINO, L. F. T.; DONZELE, J. L.; GOMES, P. G.; OLIVEIRA, R. F.; LOPES, D. C.; FERREIRA, A. S.; BARRETO, S. L. T. E.; EUCLIDES, R. F. Tabelas brasileiras para aves e suínos - composição de alimentos e exigências nutricionais. 2. ed. Viçosa, MG: Universidade Federal de Viçosa, 2011. 141 p.
STATISTICAL ANALYSES SYSTEM - SAS. SAS/ INSIGHT User'sguide. Versão 9.0 - versão para Windows. Cary: SAS Institute, 2002. CD-ROM.

SANTOS, E. L.; SANTOS, Í. V. V. S.; LIRA, R. C.; SILVA, C. F.; MOURA, S. C. S.; FERREIRA, A. J. S.; SILVA, R. M. Frequência de arraçoamento para alevinos de Tilápia do Nilo (Oreochromis niloticus). Agropecuária Técnica, Areia, v. 35, n. 1, p. 171-177, 2014.

SILVA, C. A.; FUJIMOTO, R. Y. Crescimento de tambaqui em resposta a densidade de estocagem em tanques-rede. Acta Amazonica, Manaus, v. 45, n. 3, p. 323-332, 2015.

SILVA, D. J.; QUEIROZ, A. C. Análise de alimentos: métodos químicos e biológicos. 3. ed. Viçosa, MG: Universidade Federal de Viçosa, 2002. 235 p.

SOUZA, R. C.; CAMPECHE, D. F. B.; CAMPOS, R. M. L.; FIGUEIREDO, R. A. C. R.; MELO, J. F. B. Frequência de alimentação para juvenis de tambaqui. Arquivo Brasileiro de Medicina Veterinária e Zootecnia, Belo Horizonte, v. 66, n. 3, p. 927-932, 2014.

TOLEDO, J. B.; FURLAN, A. C.; POZZA, P. C.; CARRARO, J.; MORESCO, G.; FERREIRA, S. L.; GALLEGO, A. G. Reduction of the crude protein content of diets supplemented with essential amino acids for piglets weighing 15 to 30 kilograms. Revista Brasileira de Zootecnia, Viçosa, MG, v. 43, n. 6, p. 301-309, 2014.

VIDAL JÚNIOR, M. V. Técnicas de determinação de digestibilidade e determinação de digestibilidade de nutrientes de alimentos para tambaqui (Colossoma macropomum). 2000. Tese. (Doutorado em Zootecnia) Universidade Federal de Viçosa, Viçosa, MG.

YAMAMOTO, T.; SUGITA, T.; FURUITA, H. Essential amino acid supplementation to fish meal-based diets with low protein to energy ratios improves the protein utilization in juvenile rainbow trout Oncorhynchus mykiss. Aquaculture, Amsterdam, v. 246, n. 1-4, p. 379391, 2005. 
